\title{
Elastase-1 concentration in feces of term and preterm infants aged $0-4$ months
}

\author{
Nani Dharmasetiawani*, Agus Firmansyah ${ }^{\dagger}$
}

\begin{abstract}
Abstrak
Kadar elastase-1 dalam feses menggambarkan fungsi eksokrin pankreas. Beberapa laporan telah diajukan oleh peneliti-peneliti Eropa, tetapi sejauh ini belum ada laporan dari Indonesia terutama mengenai bayi. Tujuan penelitian ini ialah untuk mengetahui kadar elastase-1 feses bayi yang berumur 1-120 hari, sebagai laporan pendahuluan penelitian tentang ontogeni elastase-1 pankreas pada bayi cukup bulan dan kurang bulan. Metoda yang dipakai ialah kadar elastase-1 dalam feses diperiksa pada 28 bayi kurang bulan dan 34 bayi cukup bulan yang sehat, berumur 1-120 hari. Hasilnya ialah kadar elastase-1 feses bayi kurang dari 14 hari berkisar di bawah $200 \mu \mathrm{g} / \mathrm{g}$ feses. Pada hari pertama $80 \%$ bayi kurang bulan dan 60\% bayi cukup bulan mempunyai kadar < 200 $\mu \mathrm{g} / \mathrm{g}$ feses, pada umur 7 hari 50\% bayi kurang bulan dan 33\% bayi cukup bulan mempunyai kadar elastase-1 $<200 \mu \mathrm{g} / \mathrm{g}$ feses. Setelah umur 14 hari, kadar elastase-1 feses ialah > $200 \mu \mathrm{g} / \mathrm{g}$ feses, tidak tergantung masa gestasi. Laporan pendahuluan ini mendukung penelitian-penelitian terdahulu yaitu kadar elastase-1 feses mencapai kadar normal setelah umur 14 hari. Penelitian lebih lanjut diperlukan untuk mengetahui kadar elastase-1 feses pada bayi umur kurang dari 14 hari. (Med J Indones 2003; 12: 69-72)
\end{abstract}

\begin{abstract}
Fecal elastase-1 concentration reflects exocrine pancreatic function. There have been some reports from Europe, but so far there has not been a report of fecal elastase-1 concentration in Indonesia, especially concerning infants. The aim of this study is to know the concentration of elastase-1 in feces of infants aged 1-120 days as a preliminary report of the study of the ontogeny of pancreatic elastase-1 in term and preterm infants. Fecal elastase-1 were measured from feces of 28 healthy preterm and 34 healthy term infants up to 120 days (4 month) of age. Elastase-1 concentration in infants less than 14 days of age fluctuated below $200 \mu \mathrm{g} / \mathrm{gram}$ feces. At the first day of life $80 \%$ preterm and $60 \%$ term infants had elastase-1 concentration less than $200 \mu \mathrm{g} / \mathrm{gram}$ feces, and by the age of 7 days $50 \%$ preterm and $33 \%$ term infants had elastase-1 concentration less than $200 \mu \mathrm{g} / \mathrm{gram}$ feces. After 14 days of age its concentration was more than $200 \mu \mathrm{g} / \mathrm{gram}$ feces, regardless of gestational age. This preliminary study corroborates supported the previous studies that the level of fecal elastase-1 reached normal level after 14 days. Future longitudinal study is needed to know elastase-1 concentration in infants less than 14 days. (Med J Indones 2003; 12: 69-72)
\end{abstract}

Keywords: Fecal elastase-1, Infants, Enzyme-link immunosorbent assay

Pancreatic elastase- 1 is one of the proteolitic enzymes produced by acinar pancreatic cells, secreted as zymogen proelastase into the duodenum, then activated by tripsin to become elastase. Elastase belongs to endopeptidase and plays a role in hydrolisis of internal peptide binding of polipeptide protein. ${ }^{1,2}$ On its way in small intestine, elastase is not broken-down and not hydrolized and still as a stable molecule in the lumen of gastrointestinal tract, so its concentration in the feces reflects pancreatic secretion. $3,4,5$

\footnotetext{
* Department of Child Health, Budi Kemuliaan Maternity Hospital, Jakarta, Jakarta, Indonesia

$\dagger$ Department of Child Health, Medical Faculty, University of Indonesia/Dr. Cipto Mangunkusumo Hospital, Jakarta, Indonesia
}

Determining elastase- 1 concentration in the feces is an indirect and non-invasive test of pancreatic function since it's easily done and not necessary to insert a pipe into duodenum. If concentration of $200 \mu \mathrm{g} / \mathrm{gram}$ feces is considered as a normal limit, sensitivity and specificity of elastase-1 concentration in feces using an enzyme-link immunosorbent assay are high, ${ }^{6,7,8}$ both of them are $93 \%$ for patients with pancreatic insufficiency. ${ }^{7}$

Studies of pancreatic elastase-1 concentration in infants showed that the concentration of more than $200 \mu \mathrm{g} / \mathrm{gram}$ feces as a normal level can be used for infants aged more than 2 weeks, regardless of gestational age, but can not be used for those aged less 
than 2 weeks. This maybe due to physiological immaturity factor. ${ }^{9}$ Studies of pancreatic elastase-1 concentration in infant's feces is still rare. There have been some reports from European researchers, ${ }^{8,9,10,11,12}$ but so far there has not been a report of elastase-1 concentration in feces in Indonesia, especially in infants.

The aim of this study is to know the concentration of elastase- 1 in term and preterm infants aged 1 day to 120 days. This is a preliminary report of the study on the ontogeny of pancreatic elastase- 1 in term and preterm infants.

\section{METHODS}

The examination of pancreatic elastase-1 concentration was done on 28 healthy preterm infants and 34 term infants who came to Budi Kemuliaan Maternity Hospital Jakarta, aged 1, 3, 7, 14, 30, 60, 90 and 120 days. Fecal specimen was taken and stored in a freezer in $-20^{\circ} \mathrm{C}$ before analysis. Fecal elastase- 1 was measured immunologically based on 2 monoclonal antibodies (ScheBo Tech, Wettenberg, Germany). ${ }^{13,14}$ Concentration less than $200 \mu \mathrm{g} / \mathrm{gram}$ feces is classified as pancreatic insuficiency. ${ }^{7,10}$ Term infant is defined as an infant born in full 37 weeks to 42 weeks of gestational age, and preterm infant is born in less than 37 weeks of gestational age. Low birth weight infant is an infant with birth weight less than 2500 grams. ${ }^{15,16}$

Fecal elastase- 1 concentrations of preterm and term infants were compared based on age groups. The data was analyzed using Mann-Whitney test. The increase of elastase- 1 concentration on preterm infant from the first to $14^{\text {th }}$ day of life was also evaluated.

\section{RESULTS}

Fecal elastase- 1 concentration of 28 preterm and 54 term infants who were born and came to Budi Kemuliaan Maternity Hospital from September 2000 to March 2001 had been measured. The preterm infants were in 30-36 weeks of gestational age (mean 34,5 weeks), and the term infants were in $38-40$ weeks of gestational age (mean 39 weeks).

Table 1 showed the elastase- 1 concentration in infants aged 1-120 days. The elastase-1 concentration in infants aged 1-14 days still fluctuated below 200 $\mu \mathrm{g} / \mathrm{gram}$ feces (Figure 1). The difference in value of elastase- 1 concentration in preterm infant and term infant was not significant (Table 1). There was a significant increase of elastase-1 concentration in preterm infant from the first day to the $14^{\text {th }}$ day of life (Table 2). At the first day of life $80 \%$ of preterm and $60 \%$ of term infants had elastase- 1 concentration less than $200 \mu \mathrm{g} / \mathrm{gram}$ feces and by the age of 7 days $50 \%$ preterm infants and $33 \%$ term infants had concentration less than $200 \mu \mathrm{g} / \mathrm{gram}$ feces.

Table 1. Elastase-1 concentration in feces*

\begin{tabular}{lccccc}
\hline $\begin{array}{c}\text { Age } \\
(\text { day })\end{array}$ & & $\begin{array}{c}\text { Preterm } \\
\text { infant }\end{array}$ & & Term infant & p \\
\cline { 2 - 5 } & $\mathbf{N}$ & $\begin{array}{c}\text { Elastase-1 } \\
\text { concentration } \\
(\boldsymbol{\mu g} / \mathbf{g} \text { feces })\end{array}$ & $\mathbf{n}$ & $\begin{array}{c}\text { Elastase-1 } \\
\text { concentration } \\
(\boldsymbol{\mu g} / \mathbf{g} \text { feces })\end{array}$ & \\
\hline 1 & 5 & $119,2 \pm 116,3$ & 5 & $193,7 \pm 97,2$ & 0,251 \\
3 & 3 & $292,4 \pm 171,4$ & 7 & $441,9 \pm 227,1$ & 0,569 \\
7 & 4 & $193,0 \pm 97,3$ & 6 & $264,8 \pm 167,1$ & 0,522 \\
14 & 4 & $303,2 \pm 41,0$ & 7 & $312,8 \pm 48,0$ & 0,850 \\
30 & 4 & $364,6 \pm 107,4$ & 8 & $348,8 \pm 114,8$ & 0,610 \\
60 & 3 & $514,2 \pm 138,9$ & 6 & $412,5 \pm 108,6$ & 0,302 \\
90 & 2 & $420,1 \pm 134,4$ & 6 & $487,9 \pm 109,0$ & 0,505 \\
120 & 3 & $416,6 \pm 162,7$ & 9 & $408,0 \pm 69,6$ & 0,644 \\
\hline
\end{tabular}

* Data is stated in mean $\pm \mathrm{SD}$

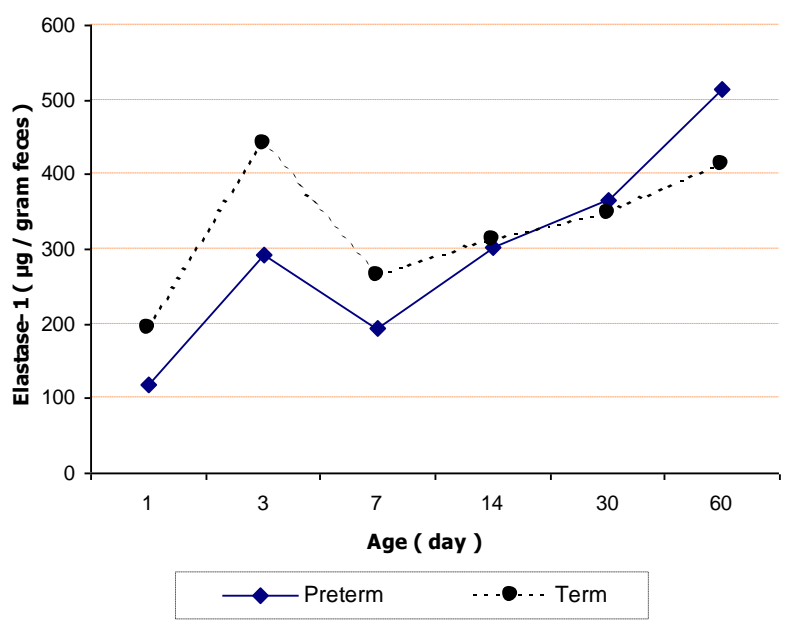

Figure 1. Elastase 1 concentration in feces of preterm and term infants 
Table 2. Elastase-1 concentration in preterm infants aged 1, 3, 7 and 14 days

\begin{tabular}{cl}
\hline Age (days) & $\begin{array}{l}\text { Elastase-1 concentration } \\
(\boldsymbol{\mu g} / \mathbf{g} \text { feces })\end{array}$ \\
\hline 1 & $119,2 \pm 116,3$ \\
3 & $292,4 \pm 171,4$ \\
7 & $193,0 \pm 97,3$ \\
14 & $303,2 \pm 41,0^{*}$ \\
\hline
\end{tabular}

*Significant difference $(\mathrm{p}<0.05)$ compared to value of 1 day.

Table 3. Infants with elastase-1 concentration less than $200 \mu \mathrm{g} /$ gram feces

\begin{tabular}{ccccccc}
\hline Age & \multicolumn{3}{c}{ Preterm } & \multicolumn{3}{c}{ Term } \\
\cline { 2 - 7 } & n & E-1 $<\mathbf{2 0 0}$ & $\mathbf{\%}$ & $\mathbf{n}$ & $\mathbf{E - 1 < 2 0 0}$ & $\mathbf{\%}$ \\
\hline 1 day & 5 & 4 & 80 & 5 & 3 & 60 \\
3 days & 3 & 1 & 33 & 7 & 1 & 14 \\
7 days & 4 & 2 & 50 & 6 & 2 & 33 \\
14 days & 4 & 0 & 0 & 7 & 0 & 0 \\
$\begin{array}{c}1-4 \\
\text { months }\end{array}$ & 12 & 0 & 0 & 29 & 0 & 0 \\
\hline Total & 28 & 7 & 25 & 54 & 6 & 11 \\
\hline
\end{tabular}

\section{DISCUSSION}

This study showed that pancreatic elastase-1 concentration in feces of infants aged less than 14 days still fluctuated below $200 \mu \mathrm{g} / \mathrm{gram}$ feces. This fluctuation of concentration were found in both preterm and term infants. In preterm infants, the elastase-1 concentration was lower than that of term infants, but the difference was not significant. After 14 days of life, the elastase- 1 concentration rate was stable over $200 \mu \mathrm{g} / \mathrm{gram}$ feces. In 1995, Terbrack et al found that the elastase- 1 concentration in meconium was $63,9 \pm 3,6 \mu \mathrm{g} / \mathrm{gram}$ feces and by the age of 1 month was $586,1 \pm 65,4 \mu \mathrm{g} / \mathrm{gram}$ feces. ${ }^{10}$ After one month, the increase of the concentration was very small and not significant. ${ }^{10,11}$ Von Seebach et al found that at the age of $0-48$ hours the elastase- 1 concentration in feces in $43 \%$ of term infants had achieved adult concentration whereas in $100 \%$ of preterm infants it was still below $30 \mu \mathrm{g} / \mathrm{gram}$ feces. By the age of 1 week, $97,4 \%$ of term infants and $85 \%$ of preterm infants had achieved normal level of concentration and after the second week both of them were stable over $200 \mu \mathrm{g} / \mathrm{gram}$ feces. ${ }^{12}$ Our study found that by the age of one day, $80 \%$ of preterm infants and $60 \%$ of term infants had concentration less than $200 \mu \mathrm{g} / \mathrm{gram}$ feces, while by the age of one week $50 \%$ of preterm infants and $33 \%$ of term infants still had concentration less than $200 \mu \mathrm{g} / \mathrm{gram}$ feces. Although the sample size of this study was small, the result was not different from the previous studies. In conclusion, this preliminary report corroborates other previous studies showed that the pancreatic elastase-1 concentration in feces in infants until the age of 14 days still fluctuated below $200 \mu \mathrm{g} / \mathrm{gram}$ feces and after 2 weeks it was stable over $200 \mu \mathrm{g} / \mathrm{gram}$ feces. Future study with larger representative sample size is needed to establish the development of pancreatic elastase- 1 concentration in infants less than 14 days.

\section{Acknowledgments}

We would like to thank Prodia Laboratory Jakarta for their help in laboratory work and some material kits. We also would like to thank Dr. Yoedo Prihartono, MPH for his help in statistical analysis.

\section{REFERENCES}

1. Castro GA. Digestion and absorption. In: Johnson LR, ed. Gastrointestinal physiology. 4th ed. St Louis: Mosby Year Book; 1991.p.108-30.

2. Schmitz J. Malabsorption. In: Walker WA, Durie PR, Hamilton JR, Walker-Smith JA, Watkins JB, eds. Pediatric gastrointestinal disease. Pathophysiology, diagnosis, management. Philadelphia: BC Decker; 1991. p.79-89.

3. Katschinski M, Schirra J, Bross A, Arnold R, Göke B. Pattern of duodenal secretion and fecal excretion of pancreatic elastase- 1 in healthy humans and patients with exocrine pancreatic insufficiency. Proceedings of The European Pancreatic Club XXVIth Meeting; 1994 Sep 710; Bologna, Italy: European Pancreatic Club 1994.

4. Dominguez-Munöz JE, Malfertheiner P, Hieronymus C, Sauerbruch T. Human elastase concentration in faeces: A simple and accurate pancreatic function test. Klin Lab 1994;40:537.

5. Dominguez-Munöz JE,Hieronymus C, Sauerbruch T, Malfertheiner P. Fecal elastase test (FET) in the diagnosis and staging of chronic pancreatitis (CP). Proceedings of The European Pancreatic Club XXVIth Meeting; 1994 Sep 7-10; Bologna, Italy: European Pancreatic Club 1994.

6. Stein J, Jung M, Zeuzem S, Lembcke B, Caspary WF. Fecal elastase-1 in pancreatic insufficiency: Corelation with the secretin-pancreozymin test. Tenth (10th) congress of gastroenterology; 1994 Oct 2-7; Los Angeles, California USA: 1994.

7. Löser C, Mölgaard A, Fölsch UR. Fecal elastase 1 : a novel, highly sensitive, and specific tubeless pancreatic function test. Gut 1996;39:580-6.

8. Soldan W, Henker J, Sprossig C. Sensitivity and specificity of quantitative determination of pancreatic 
elastase 1 in feces of children. J Ped Gastroenterol Nutr 1997;24:53-5.

9. Nissler K, Von Katte, Huebner A, Henker J. Pancreatic elastase- 1 in feces of preterm and term infants. J Ped Gastroenterol Nutr 2001;33:28-31.

10. Terbrack HG, Gürtler KH, Klör HU, Lindemann H. Human pancreatic elastase 1 concentration in faeces of healthy children and children with cystic fibrosis. Gut 1995;37 Suppl.2:253.

11. Gullo L, Graziano L, Babbini S, Battistini A, Lazzari R, Pezzilli R. Fecal elastase 1 in children with cystic fibrosis. Eur J Pediatr 1997;156:770-2.

12. Von Seebach I, Henker J. Pancreatic elastase 1 in faeces of preterm and term born infants up to 12 months without insufficiency of exocrine pancreatic function. Abstract from the 21st European Cystic Fibrosis Conference (EW6CF), Davos (Switzerland). June 1-6, 1997.
13. Stein J, Jung M, Sziegoleit A, Zeuzem S, Caspary WF, Lembcke B. Immunoreactive elastase 1: clinical evaluation of a new noninvasive test of pancreatic function. Clin Chem 1996;42:222-6.

14. Dominguez-Munöz JE, Hieronymus C, Sauerbruch T, Malfertheiner P. Fecal elastase test: Evaluation of a new noninvasive pancreatic function test. Am J Gastroenterol 1995;90:1834-7.

15. Cunningham FG, MacDonald PC, Gant NF, Leveno KJ, Gilstrap LC. Preterm and postterm pregnancy and fetal growth retardation. William Obstetrics. $19^{\text {th }}$ ed. New Yersey: Prentice Hall; 1993.p.853-89.

16. Behrman RE, Shiono Ph. Neonatal risk factors. In : Fanaroff AA, Martin RJ, eds. Neonatal-perinatal medicine. Diseases of the fetus and infant. $6^{\text {th }}$ ed. St Louis: Mosby; 1997.p.3-12. 
